\title{
In vitro assessment of the probiotic potential of lactobacilli isolated from Minas artisanal cheese produced in the Araxá region, Minas Gerais state, Brazil
}

[Avaliação in vitro do potencial probiótico de lactobacilos isolados de queijo minas artesanal produzido na região de Araxá, estado de Minas Gerais, Brasil]

\author{
J.G. Silva ${ }^{1}$, R.D. Castro ${ }^{1}$, F.M. Sant'Anna ${ }^{1}$, R.M. Barquete ${ }^{1}$, L.G. Oliveira ${ }^{1}$,
} L.B. Acurcio ${ }^{2}$, L.M.P. Luiz, ${ }^{1}$, G.A. Sales ${ }^{1}$, J.R. Nicoli ${ }^{2}$, M.R. Souza ${ }^{1}$

${ }^{1}$ Universidade Federal de Minas Gerais - Escola de Veterinária - Belo Horizonte, MG ${ }^{2}$ Universidade Federal de Minas Gerais - Instituto de Ciências Biológicas - Belo Horizonte, MG

J.G. Silva1

https://orcid.org/0000-0001-5565-7980 R.D. Castro1

https://orcid.org/0000-0003-1393-1480 F.M. Sant'Anna1

(1) R.M. Barquete1

ttps://orcid.org/0000-0002-6537-4797 L.G. Oliveira1

ittps://orcid.org/0000-0001-8920-6571 L.B. Acurcio2

https://orcid.org/0000-0002-2981-5479 L.M.P. Luiz1

https://orcid.org/0000-0003-1304-9420 G.A. Sales 1

Htps://orcid.org/0000-0001-5093-1848 J.R. Nicoli2

https://orcid.org/0000-0003-2390-2608 R. Souzal

https://orcid.org/0000-0001-7071-7304

Minas artisanal cheese is made from endogenous starter cultures, including lactic acid bacteria (LAB). Some LAB may possess probiotic potential. Thus, this study aimed to evaluate the in vitro probiotic properties of lactobacilli isolated from Minas artisanal cheeses produced in Minas Gerais. Ten samples of lactobacilli, formerly isolated from those cheeses, were submitted to the following assays: antimicrobial susceptibility, tolerance to artificial gastric juice and biliary salts, production of hydrogen peroxide and antagonism against pathogenic and non-pathogenic micro-organisms. Only L. plantarum (C0) was sensitive to all tested antimicrobials, while the other LAB samples were resistant to at least one drug. Six samples were tolerant to artificial gastric juice, and $L$. brevis (A6) even grew in that medium. Three samples were tolerant to biliary salts. Only L. brevis (E35) produced hydrogen peroxide. Difference $(\mathrm{P}<0.05)$ was observed among the means of inhibition haloes of lactobacilli against Enterococcus faecalis ATCC 19433 and Lactobacillus plantarum C24 in spot-on-the-lawn assay. All samples of lactobacilli inhibited Escherichia coli ATCC 25922, Salmonella enterica var. Typhimurium ATCC 14028 in co-culture antagonism test $(\mathrm{P}<0.0001)$. Most lactobacilli samples showed in vitro probiotic potential. From the tested samples, L. brevis (A6) presented the best results considering all in vitro probiotic tests.

Keywords: artisanal cheeses, beneficial micro-organisms, antibiogram, tolerance to gastric juice and biliary salts, antagonism

\section{RESUMO}

O queijo minas artesanal é produzido por culturas starters endógenas, incluindo bactérias ácido-láticas (BAL). Algumas BAL podem possuir potencial probiótico. Com isso, este estudo teve como objetivo avaliar as propriedades probióticas in vitro de lactobacilos isolados de queijo minas artesanal produzido no estado de Minas Gerais. Dez amostras de lactobacilos, previamente isoladas desses queijos, foram submetidas aos seguintes testes: susceptibilidade aos antimicrobianos, tolerância ao suco gástrico artificial e aos sais biliares, produção de peróxido de hidrogênio e antagonismo contra micro-organismos patogênicos e não patogênicos. Apenas L. plantarum (CO) foi sensivel a todos os antimicrobianos testados, enquanto as outras amostras de BAL foram resistentes a, pelo menos, uma droga testada. Seis amostras foram tolerantes ao suco gástrico artificial, e L. brevis (A6) apresentou crescimento nesse meio. Três amostras foram tolerantes aos sais biliares. Apenas L. brevis (E35) produziu peróxido de hidrogênio. Diferença $(P<0,05)$ foi observada entre as médias dos halos de inibição de lactobacilos contra Enterococcus faecalis ATCC 19433 e Lactobacillus plantarum C24 no teste do spot-on-the-lawn. Todas as amostras de lactobacilos inibiram Escherichia coli ATCC 25922, Salmonella enterica var. Typhimurium ATCC 14028 no teste de antagonismo em cocultura $(P<0,0001)$. A maioria das amostras de lactobacilos apresentou potencial probiótico in vitro. Com base nas amostras testadas, L. brevis (A6) apresentou os melhores resultados, considerando-se todos os testes probióticos in vitro.

Palavras-chave: queijo artesanal, micro-organismos benéficos, antibiograma, tolerância ao suco gástrico e sais biliares, antagonismo

Recebido em 18 de julho de 2017

Aceito em 17 de janeiro de 2018

E-mail: givanidojgs@gmail.com 


\section{INTRODUCTION}

Minas artisanal cheese has long been produced in some regions of Minas Gerais State, Brazil, involving a large number of small farmers, generating labor and income to their families. Its production is characterized by the use of raw milk and endogenous starter cultures and the cheeses are ripened at farms at room temperature (Dores and Ferreira, 2012).

Lactic acid bacteria (LAB) present in raw milk, endogenous cultures and the environment of the cheesemaking facilities are responsible to the fermentation and the acidifying processes that occur during artisanal cheese production, mainly during the ripening. The metabolism of this microbiota confers to the cheeses the unique characteristics of flavor and texture (Kongo et al., 2007; Dolci et al., 2008).

According to a joint of experts from the Food and Agriculture Organization of the United Nations (FAO) and World Health Organization (WHO), probiotics are "live microorganisms which when administered in adequate amounts confer a health benefit on the host" (Organização..., 2002).

LAB isolated from artisanal cheeses may possess probiotic potential, which have been investigated in vitro (Mandal et al., 2016). From the seven regions officially recognized by the Minas Gerais State government as artisanal cheese producers (Araxá, Serra da Canastra, Cerrado, Campo das Vertentes, Serro, Serra do Salitre and Triângulo), potentially probiotic LAB have been isolated from chesses produced in the Serra da Canastra region (Costa et al., 2013; Andrade et al., 2014). However, there is a lack of information concerning the probiotic potential of LAB present in Minas artisanal cheeses from the Araxá region.

Thus, this study aimed at the in vitro screening of potentially probiotic lactobacilli isolated from Minas artisanal cheeses produced in the Araxá region, Minas Gerais State.

\section{MATERIAL AND METHODS}

Ten samples of lactobacilli were previously isolated from 84 samples of Minas artisanal cheese produced in the Araxá region and were identified by $16 \mathrm{~S}$ rRNA gene sequencing according to Reysenbach et al. (2000). The samples L. brevis (A6, B16 and E35), L. casei (B5), L. plantarum (B206, C0, D4 and E5) and $L$. rhamnosus (A1 and C5) were submitted to the investigation of in vitro probiotic potential. All tests were carried out in triplicate with two repetitions each.

The antimicrobial susceptibility test was performed by the agar disk diffusion method according to Charteris et al. (1998). The isolated lactobacilli were grown on MRS agar (Oxoid, Basingstoke, England), under aerobiosis, for 24$48 \mathrm{~h}$ at $37^{\circ} \mathrm{C}$. From their colonies, concentrations of $10^{8}$ viable cells $(0,5 \mathrm{McF}$ arland scale) were prepared using $3.5 \mathrm{ml}$ of $0.85 \%$ buffered saline. Swabs from those dilutions were spread onto the surface of $14 \mathrm{~cm}$ diameter plates containing MRS agar (Oxoid). The drug disks (Oxoid) were distributed on the surface of the plates, which were incubated under aerobiosis, for $24-48 \mathrm{~h}$ at $37^{\circ} \mathrm{C}$. Then, the diameters of the inhibition zones were determined using a digital pachymeter. The antimicrobials (Oxoid®, Basingstoke, England) were: ceftazidime - CAZ $(30 \mu \mathrm{g})$, ciprofloxacin CIP $(5 \mu \mathrm{g})$, clindamycin - DA $(2 \mu \mathrm{g})$, erythromycin - E $(15 \mu \mathrm{g})$, streptomycin - S $(30 \mu \mathrm{g})$, gentamicin - GN $(10 \mu \mathrm{g})$, oxacillin - OX $(1 \mu \mathrm{g})$, penicillin - PEN (10UI), tetracycline - TE $(30 \mu \mathrm{g})$ and vancomycin - VA $(30 \mu \mathrm{g})$. Quality control of discs containing the antimicrobials was performed using Escherichia coli ATCC 25922. Lactobacilli samples were classified as resistant, moderately sensitive and sensitive to the drugs (Charteris et al., 1998).

The tolerance to artificial gastric juice was carried out according to Neumann (1991) and Silva et al. (2013). Lactobacilli samples were cultured in MRS broth (Difco Laboratories Inc., Detroit, USA) for $24 \mathrm{~h}$ at $37^{\circ} \mathrm{C}$, under aerobiosis. After growth, $1 \mathrm{~mL}$ of each culture was transferred to Eppendorf ${ }^{\circledR}$ microtubes and diluted $10 \mathrm{X}$ in $0.9 \%$ saline, $\mathrm{pH} 7.0$ (control) and in artificial gastric juice (pepsin $3 \mathrm{~g} / \mathrm{L}, \mathrm{pH} 2.0$ ). After that, $200 \mathrm{uL}$ were transferred to the wells of 96-well microplate and incubated in a spectrophotometer (Microplate Spectrophotometer System 47 SpectraMax 340 Molecular Devices, Sunnyvale, USA) for $12 \mathrm{~h}$ at $37^{\circ} \mathrm{C}$. The absorbance was determined by the $\mathrm{OD}_{620 \mathrm{~nm}}$ measured each $30 \mathrm{~min}$ and the growth 
inhibition percentage was calculated using the program Graphpad Prism 5.0 by the formula (1SG/CT) $x$ 100. SG and CT correspond to the areas under the growth curve of the bacteria treated with artificial gastric juice and control, respectively. The interpretation of the results, expressed in inhibition percentage, was proposed by Acurcio et al. (2014), as following: tolerant $<40 \%$, moderate tolerant $40-80 \%$ and sensitive higher than $80 \%$.

The tolerance to biliary salts was performed according to Walker and Gilliland (1993) and Silva et al. (2013). Lactobacilli samples were cultured in MRS broth (Difco) for $24 \mathrm{~h}$ at $37^{\circ} \mathrm{C}$, under aerobiosis. After growth, $1 \mathrm{~mL}$ of each culture was transferred to Eppendorf ${ }^{\circledR}$ microtubes, diluted $4 \%(\mathrm{v} / \mathrm{v})$ in MRS broth (Difco). Then, $100 \mu \mathrm{L}$ were transferred to a well of the 96-well microplate containing $100 \mu \mathrm{L}$ of MRS broth (Difco) and $100 \mu \mathrm{L}$ to another well containing MRS broth (Difco) added with $0.6 \%$ $(\mathrm{p} / \mathrm{v})$ biliary salts (Oxgall®). The microplates were incubated in a spectrophotometer (Microplate Spectrophotometer System SpectraMax 340 - Molecular Devices, Sunnyvale, USA) for $12 \mathrm{~h}$ at $37^{\circ} \mathrm{C}$. The absorbance was determined by the $\mathrm{OD}_{620 \mathrm{~nm}}$ measured each 30min and the growth inhibition percentage was calculated using the program Graphpad Prism 5.0 by the formula (1-SB/CT) x 100. SB and CT correspond to the areas under the growth curve of the bacteria treated with biliary salts and control, respectively. The interpretation of the results, expressed in inhibition percentage, was proposed by Acurcio et al. (2014), as following: tolerant $<40 \%$, moderately tolerant $40-80 \%$ and sensitive higher than $80 \%$.

The synthesis of hydrogen peroxide was evaluated according to the colorimetric method described by Rabe and Hillier (2003). Lactobacilli samples were cultured in MRS broth (Difco) for $24 \mathrm{~h}$ at $37^{\circ} \mathrm{C}$, under aerobiosis. After growth, $2 \mu \mathrm{L}$ were inoculated onto TMB-plus agar (Brucella agar 43.0g; tetramethylbenzidin dihydrochloride $0.25 \mathrm{~g}$; starch $20.0 \mathrm{~g}$; hemin solution $(0.05 \%), \quad 10.0 \mathrm{~mL} ; \quad \mathrm{MgSO} 4 \quad 0.57 \mathrm{~g}$; $\mathrm{MgSO} 4 . \mathrm{H} 2 \mathrm{O} 0.12 \mathrm{~g}$; peroxidase solution $(0.1 \%)$, $10 \mathrm{~mL}$; and horse serum, $50 \mathrm{~mL}$, in 1 liter of distillated water). The plates were incubated for 18 hours at $37^{\circ} \mathrm{C}$ in anaerobiosis, and then exposed to air for $30 \mathrm{~min}$. Colonies of lactobacilli were considered producers of hydrogen peroxide when showed bluish or brownish shades due to the oxidative activity. They were considered of high production $(+++)$ for brown colonies, mean producer $(++)$ for blue colonies, low producer $(+)$ for white-blue colonies and absence of production (-).

The antagonism of the lactobacilli samples against indicator bacteria was carried out by the spot-on-the-lawn assay, described by Tagg et al. (1976). The isolated bacteria were cultured in MRS broth (Difco) for $24 \mathrm{~h}$ at $37^{\circ} \mathrm{C}$ under aerobiosis. After growth, an aliquot $(5 \mu \mathrm{L})$ of the culture was spotted onto MRS agar (Difco). After incubation at $37^{\circ} \mathrm{C}$ for $48 \mathrm{~h}$ under aerobiosis, the cells were killed by exposure to chloroform during 20min. Residual chloroform was allowed to evaporate and Petri dishes were overlaid with $3.5 \mathrm{ml}$ of BHI or MRS soft $(0.7 \%)$ agar (Difco) which had been inoculated with $10 \mu \mathrm{L}$ of a $24 \mathrm{~h}$ culture of Enterococcus faecalis ATCC 19433, Escherichia coli ATCC 25922, Listeria monocytogenes ATCC 15313, Salmonella enterica var. Typhimurium ATCC 14028, Shigella flexneri ATCC 25875 and Staphylococcus aureus N315. L. plantarum C24 and $L$. rhamnosus A23, isolated from the same cheeses and molecularly identified by $16 \mathrm{~S}$ RNA gene sequencing, were also used as indicator strains. After $24 \mathrm{~h}$ of incubation at $37^{\circ} \mathrm{C}$, under aerobiosis, the plates were evaluated for the presence of a growth inhibition halo. Mean values of the inhibition haloes were compared by the Kruskal-Wallis test at 5\% significance.

The direct antagonism test (co-culture) was performed according to the method described by Hutt et al. (2006). Lactobacilli were tested against Escherichia coli ATCC 25922, Salmonella enterica var. Typhimurium ATCC 14028 and Shigella flexneri ATCC 25875. The tested bacteria were cultured in MRS (LAB) or BHI (Gram negative bacteria) broths (Difco) for $24 \mathrm{~h}$ at $37^{\circ} \mathrm{C}$ under aerobiosis. After growth, $1 \mathrm{~mL}$ of each culture was inoculated into MRS (Difco) and BHI (Difco) broths, at $1 \%$ dilution (v/v), inside Eppendorf® microtubes, which were incubated at $37^{\circ} \mathrm{C}$ for $18 \mathrm{~h}$. Then, serial dilutions of each culture were prepared using $0.9 \%$ saline and $10 \mu \mathrm{L}$ of them were spread on MacConkey agar (Difco). The plates were incubated for 24 hours, at $37^{\circ} \mathrm{C}$, under aerobiosis. After that, the colonies that grew on the agar were counted. The 
Friedman test at $0.0001 \%$ significance level was used to compare mean counts of bacteria. Control of $\mathrm{pH}$ of MRS and BHI broths after incubation under aerobiosis for $24 \mathrm{~h}$ at $37^{\circ} \mathrm{C}$ was carried out using a digital $\mathrm{pH}$ meter.

\section{RESULTS AND DISCUSSION}

The results of antimicrobial susceptibility test (Table 1) showed that only L. plantarum C0 was sensitive to all tested drugs. The other samples of Lactobacilllus spp. isolated from Minas artisanal cheeses produced in the Araxá region were resistant to at least one drug.

The results of the present study are different from the description of other researches (Costa et al., 2013; Andrade et al., 2014) that evaluated the antimicrobial susceptibility of lactic acid bacteria (LAB) isolated from Minas artisanal cheeses produced in the Serra da Canastra region. The former studies did not report any lactobacilli sensitive to all tested drugs. According to Souza et al. (2007), the sensitivity to a larger number of antimicrobials, belonging to different classes, is essential to a probiotic microorganism, since it decreases the chance of introducing genes that confer resistance to antimicrobials in an ecosystem, like the gastrointestinal tract of human beings.

L. plantarum E5 showed the highest percentage of resistance to antimicrobials $(60 \%)$ and may represent a risk to undesirable transmission of drug resistance genes. Multiple antimicrobials resistance in $\mathrm{LAB}$ isolated from cheeses is reported in the literature (Flórez et al., 2005). Consequently, there is a concern about the nonintrinsic resistance genes which may be passed to pathogens and cause problems to public health.

Table 1. Profile of antimicrobial susceptibility of lactobacilli isolated from Minas artisanal cheeses produced in the Araxá region, tested by agar disk diffusion method

\begin{tabular}{|c|c|c|c|c|c|c|c|c|c|c|}
\hline \multirow[t]{2}{*}{ Sample } & \multicolumn{10}{|c|}{ Antimicrobial } \\
\hline & GN & OX & VA & $S$ & TE & CAZ & PEN & $\mathrm{DA}$ & CIP & $\mathrm{E}$ \\
\hline L. brevis A6 & $\mathrm{S}$ & $\mathrm{R}$ & $\mathrm{R}$ & $\mathrm{S}$ & $\mathrm{S}$ & $\mathrm{S}$ & $\mathrm{S}$ & $\mathrm{S}$ & MS & $\mathrm{S}$ \\
\hline L. brevis B16 & S & $\mathrm{R}$ & $\mathrm{R}$ & $\mathrm{R}$ & MS & MS & MS & $\mathrm{R}$ & $\mathrm{R}$ & $\mathrm{S}$ \\
\hline L. brevis E35 & S & $\mathrm{R}$ & $\mathrm{R}$ & $\mathrm{R}$ & S & MS & MS & $\mathrm{R}$ & $\mathrm{R}$ & $\mathrm{S}$ \\
\hline L. casei B5 & $\mathrm{R}$ & $\mathrm{R}$ & S & $\mathrm{R}$ & S & $\mathrm{R}$ & S & S & S & $\mathrm{R}$ \\
\hline L. plantarum B206 & $\mathrm{R}$ & $\mathrm{R}$ & $\mathrm{R}$ & $\mathrm{R}$ & S & MS & S & S & MS & $\mathrm{S}$ \\
\hline L. plantarum $\mathrm{C} 0$ & S & S & S & S & S & S & S & $\mathrm{S}$ & $\mathrm{S}$ & $\mathrm{S}$ \\
\hline L. plantarum D4 & $S$ & $\mathrm{R}$ & S & MS & MS & $\mathrm{R}$ & $\mathrm{S}$ & MS & S & $\mathrm{S}$ \\
\hline L. plantarum E5 & $\mathrm{R}$ & $\mathrm{R}$ & $\mathrm{R}$ & $\mathrm{R}$ & S & $\mathrm{R}$ & $\mathrm{S}$ & S & S & $\mathrm{R}$ \\
\hline L. rhamnosus A1 & $\mathrm{R}$ & $\mathrm{R}$ & $\mathrm{R}$ & $\mathrm{R}$ & S & $\mathrm{R}$ & S & S & S & $\mathrm{S}$ \\
\hline L. rhamnosus C5 & $\mathrm{R}$ & $\mathrm{R}$ & $\mathrm{R}$ & $\mathrm{R}$ & S & $\mathrm{R}$ & $\mathrm{S}$ & $\mathrm{S}$ & MS & $\mathrm{S}$ \\
\hline
\end{tabular}

Legend: ceftazidime (CAZ), clindamycin (DA), ciprofloxacin (CIP), erythromycin (E), gentamicin (GN), oxacillin $(\mathrm{OX})$, penicillin (PEN), streptomycin (S), tetracycline (TE), vancomycin (VA). R - resistant, MS - moderately sensitive, $\mathrm{S}$ - sensitive, according to Charteris et al. (1998).

The highest sensitiveness percentages were reported to erythromycin, penicillin and tetracycline, all $80 \% \quad(8 / 10)$. Regarding penicillin, the results of the present study are similar to those reported by Danielsen and Wind (2003), describing that lactobacilli are sensitive to penicillin and other antimicrobials used in human medicine. A total of $90 \%(9 / 10)$ of the tested lactobacilli in the present study were resistant to oxacillin. Only L. plantarum C0 was sensitive to this antimicrobial, which may be associated to an intrinsic resistance, as suggested by Danielsen and Wind (2003); Mathur and Singh (2005).
Enterococcus spp., Lactobacillus spp., Leuconostoc spp. and Pediococcus spp. may show intrinsic resistance to vancomycin (Ouoba et al., 2008; Hegstad et al., 2010). However, in the present study, L. casei B5, L. plantarum C0 and L. plantarum D4 were sensitive to that drug, opposing to the results described by Costa et al. (2013) and Andrade et al. (2014), who observed $100 \%$ vancomycin resistance in samples of LAB isolated from Minas artisanal cheeses. On the other hand, Mannu et al. (2003); Herreros et al. (2005); Belletti et al. (2009); Acurcio et al. (2014) reported LAB sensitive to vancomycin, showing that resistance is not present in all samples of lactobacilli. 
From the results, it was observed that $60 \%$ of tested LAB samples showed resistance to the evaluated antimicrobials. $L$. plantarum $\mathrm{C} 0, L$. brevis A6, L. plantarum B206 and L. plantarum D4 showed the best results, with 0, 20, 20 and $40 \%$ of antimicrobial resistance, respectively.

Most lactobacilli samples were tolerant to artificial gastric juice (Table 2), especially $L$. brevis A6. Only one sample was sensitive. Since that assay mimics what may happen inside human stomach, acid-tolerant lactobacilli would survive to the stressing environment, which is essential for them to reach the intestines, where they would present probiotic activity. Similar results were described by Costa (2013) and Andrade (2014) who showed that $100 \%$ of the lactobacilli isolated from Minas artisanal cheeses from the Serra da Canastra region were tolerant to artificial gastric juice.

Table 2. Inhibition percentage and classification according to tolerance to artificial gastric juice (pH 2.0) and to biliary salts $(0.3 \%)$ of lactobacilli isolated from Minas artisanal cheeses produced in the Araxá region

\begin{tabular}{lcc}
\multicolumn{1}{c}{ Sample } & Gastric juice & Biliary salts \\
\hline L. brevis A6 & $-0.38(\mathrm{~T})$ & $36.13(\mathrm{~T})$ \\
L. brevis $\mathrm{B} 16$ & $78.15(\mathrm{MT})$ & $79.95(\mathrm{MT})$ \\
L. brevis $\mathrm{E} 35$ & $9.42(\mathrm{~T})$ & $53.31(\mathrm{MT})$ \\
L. casei B5 & $97.00(\mathrm{~S})$ & $25.40(\mathrm{~T})$ \\
L. plantarum B206 & $27.69(\mathrm{~T})$ & $66.22(\mathrm{MT})$ \\
L. plantarum C0 & $75.84(\mathrm{MT})$ & $78.21(\mathrm{MT})$ \\
L. plantarum D4 & $34.81(\mathrm{~T})$ & $64.68(\mathrm{MT})$ \\
L. plantarum E5 & $6.39(\mathrm{~T})$ & $20.69(\mathrm{~T})$ \\
L. rhamnosus A1 & $34.93(\mathrm{~T})$ & $70(\mathrm{MT})$ \\
L. rhamnosus C5 & $73.60(\mathrm{MT})$ & $61.16(\mathrm{MT})$ \\
\hline
\end{tabular}

Legend: tolerant (T); moderately tolerant (MT); sensitive (S), according to criteria established by Acurcio et al. (2014).

Tolerance to acid is common to lactobacilli. $L$. brevis A6 showed grow even in the presence of artificial gastric juice (Table 2). According to Jay (2005), some samples of that species grow in acid medium, being able to develop at $\mathrm{pH} 3.16$. According to Dunne et al. (1999), that tolerance is potentialized in probiotic samples.

The tolerance to acid of the studied LAB may also be explained by the origin of them, since they were isolated from cheeses which are an acid food. According to Resende et al. (2011), a low $\mathrm{pH}$ is present in all the cheese processing and this factor acts like a selective medium favoring acid tolerant bacteria to survive and dominate the microbiota.

The best results for the tolerance to artificial gastric juice were demonstrated by L. rhamnosus A1, L. brevis A6, L. plantarum B206, $L$. plantarum D4, L. plantarum E5 and L. brevis E35 which showed the lowest inhibition values, mainly L. brevis A6 that also was able to grow at the acid conditions, simulating the gastric environment.
Differently to the acid tolerance, the test of tolerance to biliary salts showed that $30 \%(3 / 10)$ of the lactobacilli samples were tolerant and $70 \%$ $(7 / 10)$ were moderately tolerant to that condition (Table 2). None sample was considered sensitive.

The tolerance levels of lactobacilli found in this study were lower to those reported by Andrade $e t$ al. (2014) and higher than those values described by Costa et al. (2013); both analyzed in vitro probiotic potential of LAB isolated from Minas artisanal cheese from the Serra da Canastra region. Some studies have shown variation in the tolerance to biliary salts exhibited by LAB isolated from several sources including ewe milk, canine feces, among others (Silva et al., 2013; Acurcio et al., 2014). These results indicate that bacteria originated from different environments may present distinct tolerance to biliary salts.

L. plantarum E5 showed the lowest percentage of biliary salts inhibition. LAB from the same species also presented similar behavior (Costa et al., 2013; Andrade et al., 2014). However, this tolerance is variable even for bacteria from the 
same species, as seen in Table 2. According to Ruiz-Moyano et al. (2008), tolerance to biliary salts is more dependent of the bacterial strain than of the bacterial species.

Despite of the variation of the results, none of the analyzed bacteria was considered sensitive to biliary salts, which is also desirable for the screening of probiotic samples. It is relevant to remember that biliary salts action is important to remove pathogenic bacteria from the intestines since they act like a detergent on the plasmatic membrane of the microorganisms. However, this phenomenon is not selective and also affects desirable bacteria. The mechanisms that determine the tolerance of bacteria to biliary salts are not elucidated yet. It is believed that some microorganisms produce an enzyme that hydrolyzes biliary salts avoiding their detergent action (Vinderola and Reinheimer, 2003).

L. brevis A6, L. casei B5 and L. plantarum E5 showed the best results of tolerance to biliary salts, mainly the L. plantarum E5 which showed the better capacity of survival in the intestine.

The production of hydrogen peroxide by lactobacilli has been pointed out as an important antimicrobial action. The substance acts against pathogens like Salmonella spp. (Lebeer et al., 2008; Predmore et al., 2008). Samples of peroxide-producer lactobacilli are frequently isolated from the vagina of healthy women (Servin, 2004; Martin and Suarez, 2010; Silva et al., 2013).

In the present study, only L. brevis E35 produced hydrogen peroxide $(10 \%)$ and it was considered low production $(+)$. LAB isolated from other sources, like intestinal mucous of dogs, produced hydrogen peroxide in variable amounts (8$92.8 \%$ ), indicating that the microbial habitat may influence the ability in producing that substance (Silva et al., 2013).

Most of the lactobacilli samples showed antagonism activity against indicator microorganisms (Table 3). Some differences in the antagonism against LAB used by indicator microorganisms were detected. E. faecalis ATCC 19433 was more inhibited by $L$. rhamnosus A1 than by L. plantarum $\mathrm{C} 0$ and $\mathrm{D} 4$ $(\mathrm{P}<0.05)$ while $L$. plantarum $\mathrm{C} 24$ was more inhibited by $L$. rhamnosus $\mathrm{C} 5$ than by $L$. plantarum $\mathrm{D} 4$ and L. brevis $\mathrm{B} 16(\mathrm{P}<0.05)$.

Table 3. Means of inhibition haloes ( $\mathrm{mm}$ ) lactobacilli, isolated from Minas artisanal cheeses produced in the Araxá region, against indicator microorganisms after spot-on-the-lawn assay

\begin{tabular}{ccccccccc}
\hline Sample & \multicolumn{7}{c}{ Indicator microorganism } \\
\hline & EC & EF & LM & ST & SF & SA & LP C24 & LR A23 \\
LR A1 & 57.13 & $28.86^{\text {a }}$ & 24.57 & 46.68 & 43.52 & 31.11 & $28.20^{\text {a. b }}$ & 0.00 \\
LB A6 & 45.59 & $6.27^{\text {b.c }}$ & 22.68 & 51.92 & 49.00 & 36.96 & $27.80^{\text {a. b }}$ & 0.00 \\
LB B16 & 42.49 & $5.79^{\text {b. c }}$ & 21.93 & 40.76 & 51.74 & 32.74 & $5.87^{\text {c }}$ & 8.96 \\
LC B5 & 56.28 & $16.08^{\text {a. b. c }}$ & 4.51 & 25.82 & 25.14 & 0.00 & $20.60^{\text {b.c }}$ & 0.00 \\
LP B206 & 34.08 & $26.76^{\text {a. b }}$ & 26.02 & 44.74 & 50.22 & 32.67 & $26.12^{\text {a.b.c }}$ & 0.00 \\
LP C0 & 17.11 & $0.00^{\text {c }}$ & 24.70 & 33.72 & 9.82 & 4.21 & $17.91^{\text {a.b.c }}$ & 0.00 \\
LR C5 & 52.00 & $26.86^{\text {a. b }}$ & 25.21 & 44.64 & 45.98 & 28.47 & $29.14^{\text {a }}$ & 0.00 \\
LP D4 & 21.63 & $0.00^{\text {c }}$ & 6.72 & 0.00 & 23.80 & 0.00 & $0.00^{\text {c }}$ & 0.00 \\
LP E5 & 55.80 & $17.73^{\text {a. b. c }}$ & 18.13 & 28.24 & 29.57 & 0.00 & $23.55^{\text {a.b.c }}$ & 0.00 \\
LB E35 & 45.06 & $5.85^{\text {b.c }}$ & 22.73 & 42.80 & 47.64 & 28.87 & $23.15^{\text {a.b.c }}$ & 0.00
\end{tabular}

Legend: Means followed by distinct superscript letters in the same columns are different according to Kruskal-Wallis $(\mathrm{P}<0.05)$. EC - Escherichia coli ATCC 25922; EF - Enterococcus faecalis ATCC 19433; LM - Listeria monocytogenes ATCC 15313; ST - Salmonella enterica var. Typhimurium ATCC 14028; SF - Shigella flexneri ATCC 25875; SA - Staphylococcus aureus N315, LB - Lactobacillus brevis, LC - Lactobacillus casei, LP Lactobacillus plantarum, LR - Lactobacillus rhamnosus.

Similar antagonistic activity of LAB isolated from Minas artisanal cheese from the Serro region, "coalho" cheese and Minas artisanal cheese from the Serra da Canastra region against indicator microorganisms were reported by
Alexandre et al. (2002); Guedes Neto et al. (2005); Andrade et al. (2014), respectively.

The development of $S$. aureus is associated with intrinsic factors, such as the presence of vitamins 
B (thiamine and nicotic acid), inorganic salts and amino acids, as well as the nitrogen source, especially arginine, cystein, proline and valine, as well a temperature between $7^{\circ}$ and $48^{\circ} \mathrm{C}$ (at $37^{\circ} \mathrm{C}$ considered ideal) (Adams and Moss, 2008). The presence of these factors in the culture media and environment where the tests were performed may be related to the absence of inhibition of $S$. aureus $\mathrm{N} 315$ by $L$. casei B5 and L. plantarum D4 and E5. In addition, the presence of Staphylococcus spp. in high counts in Minas artisanal cheeses described in some studies may also be associated with inhibition observed in this study (Resende et al., 2011; Castro et al., 2016). Those undesirable bacteria may produce enterotoxins in contaminated cheeses and cause food poisoning (Schelin et al., 2011). Their presence in artisanal cheeses is related to the occurrence of mastitis in herds and cheese contamination by handlers who are carriers of the bacteria (Huber et al., 2010). Thus, is very important to adopt mastitis control in dairy herds, good manufacturing practices in cheesemaking and use antagonistic LAB to avoid staphylococcal presence in artisanal cheeses.

Probably, the antagonistic activities detected in the present study were caused by the lactic acid produced by the tested LAB. This organic acid has bacteriostatic or bactericidal effect against sensitive microorganisms (Grajek et al., 2005). Bacteriocins produced by LAB may also be involved in the antagonism, since they inhibit the growth of samples of E. coli, E. faecalis, Salmonella spp. and $S$. aureus tested by the spoton-the-lawn assay (Jamuna et al., 2005; Garcia, 2006; Todorov and Dicks, 2007; Todorov, 2009).
The inhibition activity showed by $L$. brevis E35 may be related to the production of hydrogen peroxide, as previously discussed. However, it was not produced in large amounts and the antagonism of the indicator bacteria may be caused by the association of the substances described in this paragraph.

LAB should inhibit only undesirable bacteria; however, they also may alter the development of other bacteria from the same group. Considering this criterion for the screening of probiotic samples, from the tested LAB, L. plantarum D4 would be selected for use in the production of fermented dairies. That sample showed the lowest inhibitory activity against other LAB $(\mathrm{P}<$ $0.05)$.

L. rhamnosus $\mathrm{A} 1, L$. brevis $\mathrm{A} 6$ and $\mathrm{B} 16, L$. plantarum B206, L. rhamnosus $\mathrm{C} 5$ and L. brevis E35 inhibited all pathogens and also should be selected for further in vivo probiotic studies and use for cheesemaking.

The results of the co-culture antagonism assay (Table 4, 5 and 6) showed that there was reduction in bacterial counts after growth in BHI and MRS broths. However, values of bacterial counts were always higher $(\mathrm{P}<0.0001)$ after growth in BHI when compared to MRS for all co-culture antagonism against indicator pathogens (E. coli ATCC 25922, Salmonella Typhimurium ATCC 14028 and S. flexneri ATCC 25875), except for antagonism of Lactobacillus plantarum $\mathrm{C} 0$ against Shigella flexneri ATCC 25875 (P> 0.0001).

Table 4. Mean values of E. coli ATCC 25922 counts (CFU/mL) on MacConkey agar, after growth in BHI and MRS broths with or without the presence of lactobacilli isolated from Minas artisanal cheeses produced in the Araxá region

\begin{tabular}{|c|c|c|c|c|c|c|c|c|c|c|c|}
\hline \multirow[t]{2}{*}{ Broth } & \multicolumn{11}{|c|}{ Co-culture } \\
\hline & $\mathrm{EC}$ & $\mathrm{A} 1+\mathrm{EC}$ & $\begin{array}{l}\text { A6+ } \\
\text { EC }\end{array}$ & $\begin{array}{c}\text { B16+ } \\
\text { EC }\end{array}$ & $\begin{array}{c}\text { B5+ } \\
\text { EC }\end{array}$ & $\begin{array}{c}\text { B206+ } \\
\text { EC }\end{array}$ & $\begin{array}{c}\mathrm{C} 0+ \\
\mathrm{EC}\end{array}$ & $\begin{array}{c}\mathrm{C} 5+ \\
\mathrm{EC}\end{array}$ & $\begin{array}{c}\text { D4+ } \\
\text { EC }\end{array}$ & $\begin{array}{c}\text { E5+ } \\
\text { EC }\end{array}$ & $\begin{array}{c}\text { E35+ } \\
\text { EC }\end{array}$ \\
\hline BHI & $\begin{array}{c}1,18 \mathrm{x} \\
10^{5 \mathrm{a}}\end{array}$ & $\begin{array}{c}4,25 \mathrm{x} \\
10^{9 \mathrm{a}}\end{array}$ & $\begin{array}{c}3,25 \mathrm{x} \\
10^{9 \mathrm{a}}\end{array}$ & $\begin{array}{c}2.49 \mathrm{x} \\
10^{9 \mathrm{a}}\end{array}$ & $\begin{array}{c}5.42 \mathrm{x} \\
10^{9 \mathrm{a}}\end{array}$ & $\begin{array}{c}7.50 \mathrm{x} \\
10^{9 \mathrm{a}}\end{array}$ & $\begin{array}{c}6.5 \mathrm{x} \\
10^{10 \mathrm{a}}\end{array}$ & $\begin{array}{c}5.16 \mathrm{x} \\
10^{9 \mathrm{a}}\end{array}$ & $\begin{array}{c}9.17 \mathrm{x} \\
10^{9 \mathrm{a}}\end{array}$ & $\begin{array}{c}1.16 \mathrm{x} \\
10^{9 \mathrm{a}}\end{array}$ & $\begin{array}{c}1 \mathrm{x} \\
10^{9 \mathrm{~b}}\end{array}$ \\
\hline MRS & $\begin{array}{c}3,83 \mathrm{x} \\
10^{5 \mathrm{~b}}\end{array}$ & $\begin{array}{l}<1 \mathrm{x} \\
10^{1 \mathrm{~b}}\end{array}$ & $\begin{array}{l}<1 \mathrm{x} \\
10^{1 \mathrm{~b}}\end{array}$ & $\begin{array}{c}8.83 \mathrm{x} \\
10^{5 \mathrm{~b}}\end{array}$ & $\begin{array}{c}0.33 \mathrm{x} \\
10^{5 \mathrm{~b}}\end{array}$ & $\begin{array}{l}<1 \mathrm{x} \\
10^{1 \mathrm{~b}}\end{array}$ & $\begin{array}{c}3 \mathrm{x} \\
10^{6 \mathrm{~b}}\end{array}$ & $\begin{array}{l}<1 \mathrm{x} \\
10^{1 \mathrm{~b}}\end{array}$ & $\begin{array}{c}1.33 \mathrm{x} \\
10^{5 \mathrm{~b}}\end{array}$ & $1 \times 10^{5 b}$ & $\begin{array}{c}1.78 \mathrm{x} \\
10^{6 \mathrm{~b}}\end{array}$ \\
\hline
\end{tabular}

Legend: means followed by distinct superscript letters in the column row are different according to Friedman test $(\mathrm{P}<$ 0.0001). EC: Escherichia coli ATCC 25922, A1: Lactobacillus rhamnosus, A6: Lactobacillus brevis, B16: Lactobacillus brevis, B5: Lactobacillus casei, B206: Lactobacillus plantarum, C0: Lactobacillus plantarum, C5: Lactobacillus rhamnosus, D4: Lactobacillus plantarum, E5: Lactobacillus plantarum, E35: Lactobacillus brevis. 
Table 5. Mean values of Salmonella Typhimurium ATCC 14028 counts (CFU/mL) on MacConkey agar, after growth in BHI and MRS broths with or without the presence of lactobacilli isolated from Minas artisanal cheeses produced in the Araxá region

\begin{tabular}{cccccccccccc} 
& \multicolumn{10}{c}{ Co-culture } \\
\cline { 2 - 11 } Broth & ST & A1+ & A6+ & B16+ & B5+ & B206+ & C0+ & C5+ & D4+ & E5+ & E35+ \\
& & ST & ST & ST & ST & ST & ST & ST & ST & ST & ST \\
\hline \multirow{2}{*}{ BHI } & $1.11 \mathrm{x}$ & $1.5 \mathrm{x}$ & $6.25 \mathrm{x}$ & $1.3 \mathrm{x}$ & $9.58 \mathrm{x}$ & $7.50 \mathrm{x}$ & $1.17 \mathrm{x}$ & $1.39 \mathrm{x}$ & $3.59 \mathrm{x}$ & $1.3 \mathrm{x}$ & $7.41 \mathrm{x}$ \\
& $10^{10 \mathrm{a}}$ & $10^{10 \mathrm{a}}$ & $10^{9 \mathrm{a}}$ & $10^{10 \mathrm{a}}$ & $10^{9 \mathrm{a}}$ & $10^{9 \mathrm{a}}$ & $10^{10 \mathrm{a}}$ & $10^{10 \mathrm{a}}$ & $10^{9 \mathrm{a}}$ & $10^{10 \mathrm{a}}$ & $10^{9 \mathrm{a}}$ \\
MRS & $0.5 \mathrm{x}$ & $<1 \mathrm{x}$ & $<1 \mathrm{x}$ & $<1 \mathrm{x}$ & $0.5 \mathrm{x}$ & $<1 \mathrm{x}$ & $1 \mathrm{x}$ & $<1 \mathrm{x}$ & $0.33 \mathrm{x}$ & $1 \mathrm{x}$ & $<1 \mathrm{x}$ \\
& $10^{5 \mathrm{~b}}$ & $10^{1 \mathrm{~b}}$ & $10^{1 \mathrm{~b}}$ & $10^{1 \mathrm{~b}}$ & $10^{5 \mathrm{~b}}$ & $10^{1 \mathrm{~b}}$ & $10^{5 \mathrm{~b}}$ & $10^{1 \mathrm{~b}}$ & $10^{5 \mathrm{~b}}$ & $10^{5 \mathrm{~b}}$ & $10^{1 \mathrm{~b}}$
\end{tabular}

Legend: means followed by distinct superscript letters in the same column are different according to Friedman test (P< 0.0001). ST: Salmonella Typhimurium ATCC 14028, A1: Lactobacillus rhamnosus, A6: Lactobacillus brevis, B16: Lactobacillus brevis, B5: Lactobacillus casei, B206: Lactobacillus plantarum, C0: Lactobacillus plantarum, C5: Lactobacillus rhamnosus, D4: Lactobacillus plantarum, E5: Lactobacillus plantarum, E35: Lactobacillus brevis.

Table 6. Mean values of Shigella flexneri ATCC 25875 counts (CFU/mL) on MacConkey agar, after growth in BHI and MRS broths with or without the presence of lactobacilli isolated from Minas artisanal cheeses produced in the Araxá region

\begin{tabular}{|c|c|c|c|c|c|c|c|c|c|c|c|}
\hline \multirow[t]{2}{*}{ Broth } & \multicolumn{11}{|c|}{ Co-culture } \\
\hline & SF & $\begin{array}{c}\mathrm{A} 1+ \\
\mathrm{SF}\end{array}$ & $\begin{array}{c}\mathrm{A} 6+ \\
\text { SF }\end{array}$ & $\begin{array}{c}\text { B16+ } \\
\text { SF }\end{array}$ & $\begin{array}{c}\text { B5+ } \\
\text { SF }\end{array}$ & $\begin{array}{c}\text { B206+ } \\
\text { SF }\end{array}$ & $\begin{array}{c}\mathrm{C} 0+ \\
\mathrm{SF}\end{array}$ & $\begin{array}{c}\mathrm{C} 5+ \\
\text { SF }\end{array}$ & $\begin{array}{c}\text { D4+ } \\
\text { SF }\end{array}$ & $\begin{array}{c}\text { E5+ } \\
\text { SF }\end{array}$ & $\begin{array}{c}\text { E35+ } \\
\text { SF }\end{array}$ \\
\hline BHI & $\begin{array}{c}4 \mathrm{x} \\
10^{9 \mathrm{a}}\end{array}$ & $\begin{array}{c}9.16 \mathrm{x} \\
10^{9 \mathrm{a}}\end{array}$ & $\begin{array}{c}5.25 \mathrm{x} \\
10^{9 \mathrm{a}}\end{array}$ & $\begin{array}{c}1 \mathrm{x} \\
10^{10 \mathrm{a}}\end{array}$ & $\begin{array}{c}1 \mathrm{x} \\
10^{10 \mathrm{a}}\end{array}$ & $\begin{array}{c}5 \mathrm{x} \\
10^{9 \mathrm{a}}\end{array}$ & $\begin{array}{l}3.92 \\
\times 10^{9}\end{array}$ & $\begin{array}{c}6.58 \mathrm{x} \\
10^{9 \mathrm{a}}\end{array}$ & $\begin{array}{c}1.4 \mathrm{x} \\
10^{9 \mathrm{a}}\end{array}$ & $\begin{array}{c}5.50 \mathrm{x} \\
10^{9 \mathrm{a}}\end{array}$ & $\begin{array}{c}9.33 \\
\times 10^{9 a}\end{array}$ \\
\hline MRS & $\begin{array}{c}1.66 \mathrm{x} \\
10^{5 \mathrm{~b}}\end{array}$ & $\begin{array}{l}<1 \mathrm{x} \\
10^{1 \mathrm{~b}}\end{array}$ & $\begin{array}{l}<1 \mathrm{x} \\
10^{1 \mathrm{~b}}\end{array}$ & $\begin{array}{l}<1 \mathrm{x} \\
10^{1 \mathrm{~b}}\end{array}$ & $\begin{array}{l}<1 \mathrm{x} \\
10^{1 \mathrm{~b}}\end{array}$ & $\begin{array}{l}<1 \mathrm{x} \\
10^{1 \mathrm{~b}}\end{array}$ & $\begin{array}{c}1.50 \mathrm{x} \\
10^{5}\end{array}$ & $\begin{array}{l}<1 \mathrm{x} \\
10^{1 \mathrm{~b}}\end{array}$ & $\begin{array}{l}<1 \mathrm{x} \\
10^{1 \mathrm{~b}}\end{array}$ & $\begin{array}{l}<1 \mathrm{x} \\
10^{1 \mathrm{~b}}\end{array}$ & $\begin{array}{c}0.17 \mathrm{x} \\
10^{5 \mathrm{~b}}\end{array}$ \\
\hline
\end{tabular}

Legend: means followed by distinct superscript letters in the same column are different according to Friedman test (P< 0.0001). SF: Shigella flexneri ATCC 25875, A1: Lactobacillus rhamnosus, A6: Lactobacillus brevis, B16: Lactobacillus brevis, B5: Lactobacillus casei, B206: Lactobacillus plantarum, C0: Lactobacillus plantarum, C5: Lactobacillus rhamnosus, D4: Lactobacillus plantarum, E5: Lactobacillus plantarum, E35: Lactobacillus brevis.

The co-culture antagonism results indicate that the pathogenic bacteria inhibition was more accentuated when they were previously incubated in the presence of lactobacilli. It may be explained by the production of antimicrobial substances (mainly organic acids) when LAB were cultured in MRS broth together with the pathogens.

Hutt et al. (2006) observed antagonistic activity of probiotic samples of Lactobacillus spp. and Bifidobacterium spp. against E. coli, Salmonella enterica spp. enterica and Shigella sonnei. They suggested that the antagonism was favored in liquid medium due to the fast diffusion of antimicrobial substances, like organic acids. Garcia (2006) also suggested an association between the antagonistic activity of lactobacilli with the production of organic acids leading to a $\mathrm{pH}$ decline.
An accentuated decrease in $\mathrm{pH}$ of MRS broth after growth of all tested lactobacilli was observed. Thus, the LAB acidified the medium to a lower $\mathrm{pH}$ values than did the pathogens after growth in BHI broth (Table 7), demonstrating their higher potential in production of acid and survivor in a lower $\mathrm{pH}$.

The $\mathrm{pH}$ of MRS broth after incubation of $L$. rhamnosus $\mathrm{A} 1$ and $\mathrm{C} 5, L$. brevis $\mathrm{A} 6$ and $L$. plantarum B206 was lower than control. The same LAB samples totally inhibited the three indicator pathogens, strengthening the hypothesis that the antagonistic effect was caused due to the production of organic acids. It may be stressed that $E$. coli, $S$. Typhimurium and $S$. flexneri requires minimum $\mathrm{pH}$ values of $4.5,4.5$ and 5.5, respectively, for growing (Jay, 2005; Cardoso and Carvalho, 2006). 
Table 7. Mean values of $\mathrm{pH}$ of MRS and BHI broths after incubation of lactobacilli and pathogens, respectively, for $24 \mathrm{~h}$ at $37^{\circ} \mathrm{C}$

\begin{tabular}{lc}
\multicolumn{1}{c}{ Sample } & MRS broth \\
\hline L. rhamnosus A1 & 3.86 \\
L. brevis A6 & 3.83 \\
L. brevis B16 & 4.15 \\
L. casei B5 & 4.65 \\
L. plantarum B206 & 3.72 \\
L. plantarum C0 & 4.38 \\
L. rhamnosus C5 & 3.72 \\
L. plantarum D4 & 3.96 \\
L. plantarum E5 & 4.62 \\
L. rhamnosus A1 & 4.74 \\
Control* & 6.24 \\
& BHI broth \\
Escherichia coli ATCC 25922 & 6.73 \\
Salmonella Typhimurium & 6.76 \\
ATCC 14028 & 6.77 \\
Shigella flexneri ATCC 25875 & 7.25 \\
Control** & \\
\hline Legend: * MRS control broth, incubated without \\
bacterial inoculation ** BHI control broth, incubated \\
without bacterial inoculation.
\end{tabular}

L. rhamnosus $\mathrm{A} 1$ and $\mathrm{C} 5$, L. brevis $\mathrm{A} 6$ and $L$. plantarum B206 showed the best results in coculture antagonism, since they totally inhibited the growth of the three indicator pathogens, followed by $L$. brevis B16 which inhibited the growth of $S$. flexneri ATCC 25875 and $S$. Typhimurium ATCC 14028; L. casei B5, L. plantarum D4 and L. plantarum E5 which totally inhibited the growth of S. flexneri ATCC 25875 and $L$. brevis E35 which totally inhibited the growth of $S$. Typhimurium ATCC 1402.

\section{CONCLUSIONS}

Lactobacilli isolated from Minas artisanal cheeses produced in the Araxá region showed in vitro probiotic potential. From the tested samples, L. brevis A6 presented sensitivity to antimicrobial drugs, tolerance to artificial gastric juice and biliary salts and antagonism against reference pathogens. Considering the in vitro probiotic potential, L. brevis A6 was selected for future in vivo assays in order to fulfill its probiotic screening and will be used for the elaboration of probiotic fermented foods.

\section{ACKOWLEDGEMENTS}

The authors thank Empresa de Assistência Técnica e Extensão Rural do Estado de Minas Gerais - EMATER (Araxá, Brazil) and Instituto Mineiro de Agropecuária - IMA (Belo Horizonte, Brazil) for helping with contact with cheese producers and sampling collection. We also thank Fundação de Amparo a Pesquisa do Estado de Minas Gerais - FAPEMIG (Belo Horizonte, Brazil) and Conselho Nacional de Desenvolvimento Científico e Tecnológico (CNPq) for the financial support.

\section{REFERENCES}

ACURCIO, L.B.; SOUZA, M.R.; NUNES, A.C. et al. Isolation, enumeration, molecular identification and probiotic potential evaluation of lactic acid bacteria isolated from sheep milk. Arq. Bras. Med. Vet. Zootec., v.66, p.940-948, 2014.

ADAMS, M.R.; MOSS, M.O. Food microbiology. 3.ed. Cambridge: Royal Society of Chemistry, 2008. 48p.

ALEXANDRE, D.P.; SILVA, M.R.; SOUZA, M.R.; SANTOS, W.L.M. Atividade antimicrobiana de bactérias lácticas isoladas de queijo de Minas artesanal do Serro (MG) frente a microrganismos indicadores. Arq. Bras. Med. Vet. Zootec., v.54, p.424-428, 2002.

ANDRADE, C.R.G.; SOUZA, M.R.; PENNA, C.F.A.M. et al. Propriedades probióticas in vitro de lactobacilli isolados de queijos Minas artesanais da Serra da Canastra - MG. Arq. Bras. Med. Vet. Zooect., v.66, p.1592-1600, 2014.

BELLETTI, N.; GATTI, M.; BOTTARI, B. Antibiotic resistance of Lactobacilli isolated from two Italian hard cheeses. J. Food Prot., v.72, p.2162-2169, 2009.

CARDOSO, T.G.; CARVALHO, V.M. Toxinfecção alimentar por Salmonella spp. Rev. Inst. Ciênc. Saúde, v.24, p.95-101, 2006.

CASTRO, R.D.; OLIVEIRA, L.G.; SANT'ANNA, F.M. et al. Lactic acid microbiota identification in water, raw milk, endogenous starter culture, and fresh Minas artisanal cheese from the Campo das Vertentes region of Brazil during the dry and rainy seasons. J. Dairy Sci., v.99, p.6086-6096, 2016. 
CHARTERIS, W.P.; KELLY, P.; MORELLI, L. Antibiotic susceptibility of potentially probiotic Lactobacillusspecies. J. Food Prot., v.61, p.1636-1643, 1998

COSTA, H.H.S.; SOUZA, M.R.; ACURCIO, L.B. et al. Potencial probiótico in vitro de bactérias ácido-láticas isoladas de queijo-deMinas artesanal da Serra da Canastra, MG. Arq. Bras. Med. Vet. Zootec., v.65, p.1858-1866, 2013.

DANIELSEN, M.; WIND, A. Susceptibility of Lactobacillus spp. to antimicrobial agents. Int. J. Food Microbiol., v.82, p.1-11, 2003.

DOLCI, P.; ALESSANDRIA, V.; ZEPPA, G.; COCOLIN, L.L. Microbiological characterization of artisanal Raschera PDO cheese: analysis of its indigenous lactic acid bacteria. Food Microbiol., v.25, p.392-399, 2008.

DORES, M.T.; FERREIRA, C.L.L.F. Queijo minas artesanal, tradição centenária: ameaças e desafios. Rev. Bras. Agropecu. Susten., v.2, p.2634, 2012.

DUNNE, C.; MURPHY, L.; FLYNN, S. et al. Probiotics: from myth to reality. Demonstration of functionality in animal models of disease and in human clinical trials. Antonie Leeuwenhoek, v.76, p.279-292, 1999.

FLÓREZ, A.B.; DELGADO, S.; MAYO, B. Antimicrobial susceptibility of lactic acid bacteria isolated from a cheese environment. Can. J. Microbiol., v.51, p.51-58. 2005.

GARCIA, G.R. Inhibition of the growth of pathogenic bacteria by Lactobacillus acidophilus. Rev. Port. Cienc. Vet., v.101, p. 263-268, 2006.

GRAJEK, W.; OLEJNIK, A.; SIP, A. Probiotics, prebiotics and antioxidants as functional foods. Acta Biochim. Pol., v.52, p.665-671, 2005.

GUEDES NETO, L.G.; SOUZA, M.R.; NUNES, A.C. et al. Atividade antimicrobiana de bactérias ácido-lácticas isoladas de queijos de coalho artesanal e industrial frente a microrganismos indicadores. Arq. Bras. Med. Vet. Zootec., v.57, p.245-250, 2005.
HEGSTAD, K.; MIKALSEN, T.; COQUE, T.M. Mobile genetic elements and their contribution to the emergence of antimicrobial resistant Enterococcus faecalis and Enterococcus faecium. Clin. Microbiol. Infect., v.16, p.541554, 2010.

HERREROS, M.A.; SANDOVAL, H.; GONZÁLEZ, L. Antimicrobial activity and antibiotic resistance of lactic acid bacteria isolated form Armada cheese (a Spanish goat's milk cheese). J. Food Microbiol., v.22, p.455459, 2005.

HUBER, H.; KOLLER, S.; GIEZENDANNER, N. et al. Prevalence and characteristics of meticillin-resistant Staphylococcus aureus in humans in contact with farm animals, in livestock, and in food of animal origin, Switzerland, 2009. Euro Surveill., v.15, p.19542, 2010.

HUTT, P.; SHCHEPETOVA, J.; LÕIVUKENE, $\mathrm{K}$. et al. Antagonistic activity of probiotic lactobacilli and bifidobacteria against entero- and uropathogens. J. Appl. Microbiol., v.100, p.13241332, 2006.

JAMUNA, M.; BABUSHA, S.T.; JEEVARATNAM, K. Inhibitory efficacy of nisin and bacteriocins from Lactobacillus isolates against food spoilage and pathogenic organisms in model and food systems. J. Food Microbiol., v.22, p.449-454, 2005.

JAY, J.M. Modern food microbiology. 7.ed. New York: Springer, 2005. 790p.

KONGO, J.M.; HO, A.J.; MALCATA, F.X.; WEIDMANN, M. Characterization of dominant lactic acid bacteria isolated from São Jorge cheese, using biochemical and ribotyping methods. J. Appl. Microbiol., v.103, p.18381844, 2007.

LEBEER, S.; VANDERLEYDEN, J.; DE KEERSMAECKER, S.C.J. Genes and molecules of lactobacilli supporting probiotic action. Microbiol. Mol. Biol. Rev., v.72, p.728-764, 2008.

MANDAL, H.; JARIWALA, R.; BAGCHI, T. Isolation and characterization of lactobacilli from human faeces and indigenous fermented foods for their potential application as probiotics. Can. J. Microbiol., v.62, p.349-359, 2016. 
MANNU, L.; PABA, A.; DAGA, E. et al. Comparison of the incidence of virulence determinants and antibiotic resistance between Enterococcus faecium strains of dairy, animal and clinical origin. Int. J. Food Microbiol., v.88, p.291-304, 2003.

MARTIN, R.; SUAREZ, J.E. Biosynthesis and degradation of $\mathrm{H}_{2} \mathrm{O}_{2}$ by vaginal lactobacilli. Appl. Environ. Microbiol., v.76, p.400-405, 2010.

MATHUR, S.; SINGH, R. Antibiotic resistance in food lactic acid bacteria - a review. Int. J. Food Microbiol., v.105, p.281-295, 2005.

NEUMANN, E. Comportamento "in vitro" de estirpes de Lactobacillus acidophilus sensível $e$ resistente à bacteriocina sob condições do trato digestivo. 1991. 86f. Dissertação (Mestrado em Ciência e Tecnologia de Alimentos) Universidade Federal de Viçosa, Viçosa, MG.

ORGANIZAÇÃO das Nações Unidas para a Alimentação e Agricultura. WHO - Working group report on drafting guidelines for the evaluation of probiotics in food. London, Ontario: FAO, 2002.

OUOBA, L.I.I.; LEI, V.; JENSEN, L.B. Resistance of potential probiotic lactic acid bacteria and bifidobacteria of African and European origin to antimicrobials: determination and transferability of the resistance genes to other bacteria. Int. J. Food Microbiol., v.121, p.217-224, 2008.

PREDMORE, R.D.; PITTET, A.; PRAPLAN, F.; CAVADINI, C. Hydrogen peroxide production by Lactobacillus johnsonii NCC533 and its role in anti Salmonella activity. FEMS Microbiol. Lett., v.283, p.210-215, 2008.

RABE, L.K.; HILLIER, S.L. Optimization of media for detection of hydrogen peroxide production by Lactobacillus species. J. Clin. Microbiol., v.41, p.3260-3264, 2003. RESENDE, M.F.S.; COSTA, H.H.S.; ANDRADE, E.H.P. et al. Queijo de Minas artesanal da Serra da Canastra: influência da altitude das queijarias nas populações de bactérias acido lácticas. Arq. Bras. Med. Vet. Zootec., v.63, p.1567-1573, 2011.

REYSENBACH, A.L.; LONGNECKER, K.; KIRSHTEIN, J. Novel bacterial and archaeal lineages from an in situ growth chamber deployed at a mid-atlantic ridge hydrothermal vent. Appl. Environ. Microbiol., v.66, p.37983806, 2000.
RUIZ-MOYANO, S. et al. Screening of lactic acid bacteria and bifidobacteria for potential probiotic use in Iberian dry fermented sausages. Meat Sci., v.80, p.715-721, 2008.

SCHELIN, J.; WALLIN-CARLQUIST, N.; COHN, M.T. et al. The formation of Staphylococcus aureus enterotoxin in food environments and advances in risk assessment. Virulence, v.2, p.580-592. 2011.

SERVIN, A.L. Antagonistic activities of lactobacilli and bifidobacteria against microbial pathogens. FEMS Microbiol. Rev., v.28, p.405440, 2004.

SILVA, B.C.; JUNG, L.C.R.; SANDES, S.H.C. et al. In vitro assessment of functional properties of lactic acid bacteria isolated from faecal microbiota of healthy dogs for potential use as probiotics. Benef. Microbiol., v.4, p.267-275, 2013.

SOUZA, M.R.; MOREIRA, J.L.; BARBOSA, F.H.F. et al. Influence of intensive and extensive breeding on lactic acid bacteria isolated from Gallus gallus domesticusceca. Vet. Microbiol., v.120, p.142-150, 2007.

TAGG, J.R.; DAJANI, A.S.; WANNAMAKER, L.W. Bacteriocins of Gram-positive bacteria. Bacteriol. Rev., v.40, p.722-756, 1976.

TODOROV, S.D. Bacteriocins from Lactobacillus plantarum - production, genetic organization and mode of action. Braz. J. Microbiol., v.40, p.209-221, 2009.

TODOROV, S.D.; DICKS, L.M.T. Bacteriocin production by Lactobacillus pentosus st712bz isolated from boza. Braz. J. Microbiol., v.38, p.166-172, 2007.

VINDEROLA, C.G.; REINHEIMER, J.A. Lactic acid starter and probiotic bacteria: a comparative "in vitro" study of probiotic characteristics and biological barrier resistance. Food Res. Int., v.36, p.895-904, 2003.

WALKER, D.K.; GILLILAND, S.E. Relationships among bile tolerance, bile salt deconjugation, and assimilation of cholesterol by Lactobacillus acidophilus. J. Dairy Sci., v.76, p.956-961, 1993. 